\title{
Uranium even isotopes in kimberlites, enclosing and overburden rocks of the Zolotitskoye ore field (Arkhangelsk diamondiferous province)
}

\author{
G. P. Kiselev' ${ }^{1}$ E. Yu. Yakovlev ${ }^{1}$, S. V. Druzhinin ${ }^{1}$, S. B. Zykov ${ }^{1}$, V. M. Bykov², and
} A. A. Ocheretenko ${ }^{1}$

Received 6 March 2018; accepted 2 April 2018; published 14 June 2018.

To confirm the presence of geophysical anomaly the isotopic composition of uranium has been studied from the samples extracted from the exploration wells drilled in different years in the territory of the Zolotitskoye ore field of the Arkhangelsk diamondiferous province (ADP). The study was based on the heterochronous deposits of the geologic profile and managed to obtain data on isotopic composition of uranium. For the quaternary deposits and coal formations, which are overburden ones in the Zolotitskoye ore field kimberlites, and in the Vendian rocks, which enclose kimberlites, the average values of isotopic ratio ${ }^{234} \mathrm{U} /{ }^{238} \mathrm{U}$ did not exceed 1 . Most samples from the near-contact zone, which are represented by the upper Vendian deposits and by the peripheral part of crater facies of pipes, contained excessive amounts of the daughter isotope ${ }^{234} \mathrm{U}$. The generation of high $\gamma={ }^{234} \mathrm{U} /{ }^{238} \mathrm{U}$ values is explained as being related to the geologic structure of the near-contact zone. The particular features of the ${ }^{234} \mathrm{U}$ isotope distribution are consistent with the tectonic and substantial changes in the rocks within the near-contact zone. This phenomenon has also been evidenced by several other investigators. The generation mode of non-equlibrium uranium with the excessive ${ }^{234} \mathrm{U}$ content is explained by the dynamics and circulation of underground waters along the tectonic fractures bounding the pipes. The empirical data obtained in the course of the laboratory tests allow to conclude with a certain degree of scepticism that non-equilibrium uranium in enclosing rocks relates to kimberlite magmatism in the ADP territory. In turn, non-equilibrium uranium with the excessive content of ${ }^{234} \mathrm{U}$, which was discovered in the geologic profile of enclosing Vendian deposits, may be considered as the local indirect evidence of ADP kimberlite bodies. However, when estimating the prospecting areas for availability of the kimberlite magmatism in the geologic profiles of exploration wells, the non-equilibrium state of uranium should be considered only in conjunction with the kimberlite signs. KEYWORDS: Non-equilibrium uranium; kimberlites; alpha-activity; isotope fractionation; geochemical indicators.

Citation: Kiselev, G. P., E. Yu. Yakovlev, S. V. Druzhinin, S. B. Zykov, V. M. Bykov, and A. A. Ocheretenko (2018), Uranium even isotopes in kimberlites, enclosing and overburden rocks of the Zolotitskoye ore field (Arkhangelsk diamondiferous province), Russ. J. Earth. Sci., 18, ES3002, doi:10.2205/2018ES000622.

\footnotetext{
${ }^{1}$ N. Laverov Federal Centre for Integrated Arctic Research (FCIARctic), Arkhangelsk, Russia

${ }^{2}$ Northern (Arctic) Federal University, Arkhangelsk, Russia
}

Copyright 2018 by the Geophysical Center RAS. http://rjes.wdcb.ru/doi/2018ES000622-res.html

\section{Introduction}

Since the discovery of the first kimberlite pipe in the territory of the Arkhangelsk diamondiferous province (ADP) a lot of classical geophysical methods for the prospect of the kimberlite bodies have been published; however, the most ef- 
fective among all these methods, similar to those in many other diamondiferous provinces all over the world, proved to be the aeromagnetic methods [Cyganov et al., 2004, Kontarovich and Cyganov, 2000. At the same time, magnetic surveys in the Arkhangelsk province territory nowadays face hard times. It is reflected in an abrupt decrease in its prospecting effectiveness not exceeding $0.5 \%$ [Korotkov, 2011. Stognij and Korotkov, 2010. Other geophysical, geochemical and placer-mineralogical methods have not brought to stable the prospecting effectiveness. Pursuant to conclusions made by some investigators [Androsov et al., 2004; Antonov et al., 2004, Frolov et al., 2005. Ignatov et al., 2011; Lapin and Tolstov, 2007, the main negative factors, complicating kimberlites exploration in this territory are as follows: a heavy sheath of the overburden deposits; the hidden type of fractures controlling the location of kimberlite bodies; weak kimberlite manifestation in physical fields; weak erosional truncation of pipes; an extremely low content of ferromagnetic minerals in pipes; a low content of the diamonds accessory minerals. In this regard, the necessity of development of new approaches for kimberlite pipes prospecting and their implementation into the practical prospecting activities are of especial importance.

The published actual data relating to the Russian and foreign diamondiferous provinces show potential application of some radioisotope methods for searching and prospecting of kimberlite pipes. [Magomedova and Udoratin, 2016, Magomedova et al., 2015. McDowall and Koketso, 1991. Mwenifumbo and Kjarsgaard, 1999, Ramadass et al., 2015, Zaripov, 2014. One of these techniques is based on the usage of tracer elements, such as uranium even isotopes, which are contained in all types of rocks and natural waters. The activity ratio of uranium even isotopes, which is represented by the value of $\gamma={ }^{234} \mathrm{U} /{ }^{238} \mathrm{U}$, is widely used in geology and hydrogeology. For all types of rocks with the age of 1 million year and more, the isotope ratio ${ }^{234} \mathrm{U} /{ }^{238} \mathrm{U}$ is equal to 1 and that is why the alteration of this value caused by the concentration or leaching (extraction) of the daughter isotope ${ }^{234} \mathrm{U}$ is an indicator of geochemical activity of the geological environment [Chalov et al., 1990. Titaeva, 2005. Tihonov, 2009.

The first surveys of even uranium isotopes in kimberlites were conducted for the pipes of the
Yakutsk diamondiferous province (YaDP) [Zverev et al., 1976, 1979. It was shown that in general kimberlites preserve the uranium isotope ratio near to the equilibrium one. A non-equilibrium isotope ratio was detected for several samples of the damaged kimberlites associated with water-bearing formations. In the course of investigations of the uranium isotope composition in kimberlites and in the enclosing rocks of Mir and Sputnik pipes at YaDP, it was shown for the first time that in the enclosing rock within the zone of fracture associated with the near-contact zone, the imbalance of the isotope equilibrium takes place [Kiselev, 1999]. The first investigations of the uranium isotope ratio at $\mathrm{ADP}$ were fulfilled for the Nyonokskoye field pipe, and in the geologic profile of Vendian deposits within the pipe endocontact, which have been passed by G440/1 well, high activity values of the ${ }^{234} \mathrm{U}$ light isotope have been detected [Kiselev et al., 2011. This presupposition was verified for the pipes of the Zolotitskoye ore field of ADP as exemplified by the Pionerskaya pipe [Yakovlev et al., 2016. In the near-contact zone of this pipe represented by the Vendian sands, an abrupt imbalance of the ${ }^{234} \mathrm{U}$ and ${ }^{238} \mathrm{U}$ isotopes equilibrium has been established. The isotope ratio $\gamma={ }^{234} \mathrm{U} /{ }^{238} \mathrm{U}$ reached the value of 3.57 , while the uranium isotope composition in the enclosing rocks far away from the pipe was in equilibrium. Besides, highly excessive compositions of uranium-234 also were detected for the underground waters, which circulate nearby the kimberlite bodies of ADP [Kiselev, 2005].

The identified behavior of the way the uranium isotopes fractionate in the kimberlite magmatism of ADP has caused the necessity of more extensive investigation of ${ }^{234} \mathrm{U}$ and ${ }^{238} \mathrm{U}$ distribution characteristics. In order to use the ${ }^{234} \mathrm{U} /{ }^{238} \mathrm{U}$ isotope ratio as a local evidence of kimberlite pipes one should solve several tasks. The first task is to study the particular features of the uranium isotopes distribution in the heterochronous deposits of the sedimentary sheath in the ADP. The second task is to establish the common patterns of the ${ }^{234} \mathrm{U} /{ }^{238} \mathrm{U}$ isotope ratio changes for the geologic profile of enclosing and overburden deposits. And finally, the third task is to reveal the factors causing generation of false local geochemical anomalies not connected with kimberlite pipes. An attempt to solve these tasks is presented in this work.

The research took place within the Zolotitskoye 


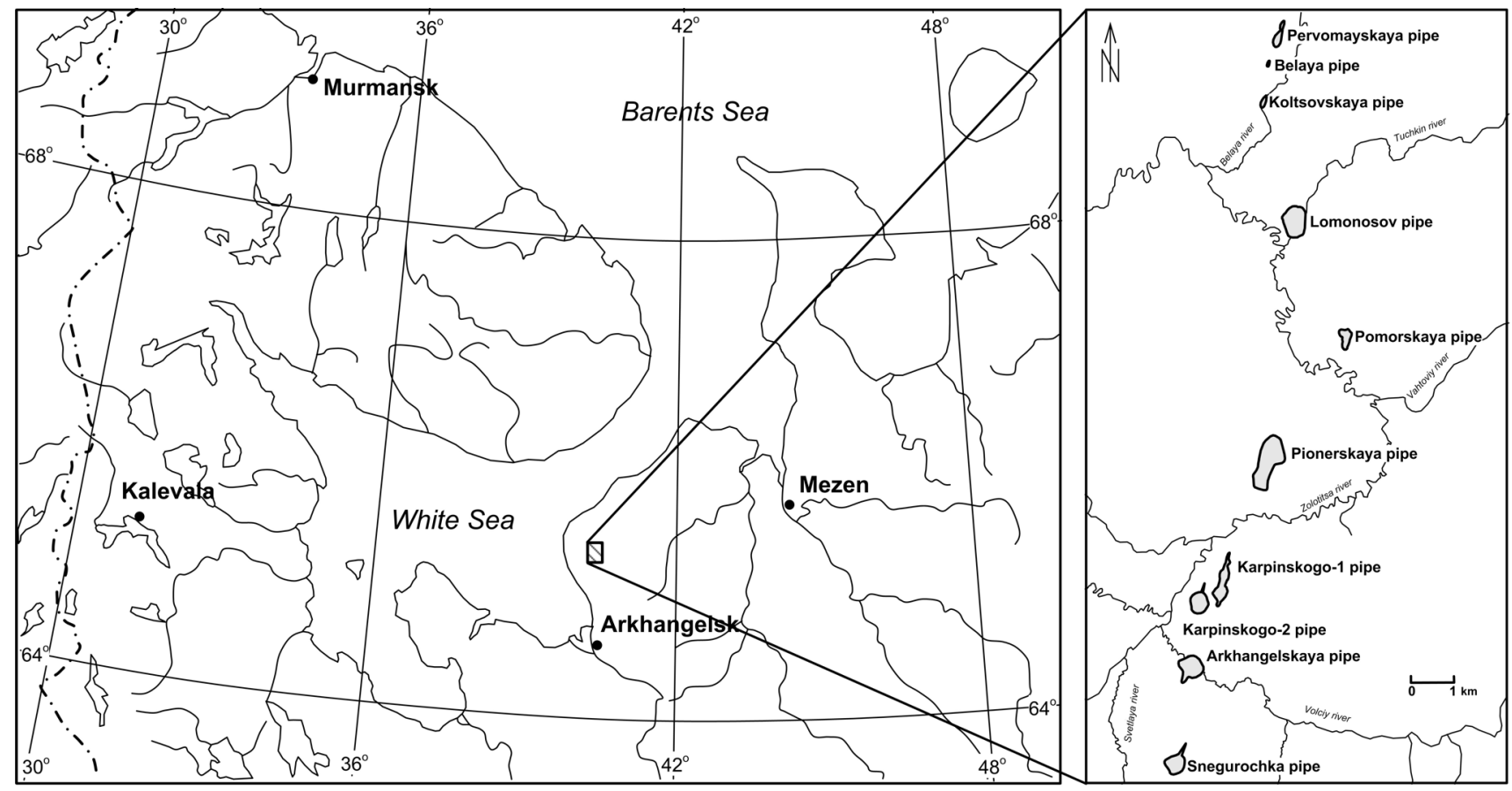

Figure 1. The location of the research area is the Zolotitskiy kimberlite field of the Arkhangelsk diamondiferous province.

kimberlite field of the Zimneberezhnyi diamondiferous region of ADP, which is located in the northern part of the Russian plate, where it joins the Baltic crystalline shield [Gubajdullin, 2002].

Nowadays, the Zimneberezhnyi region is the only region within ADP, where the industrial diamond content is established.

This region is located on the southeast coast of the White Sea, between the Dvina and Mezen Bays, and represents itself a flat land divided by the valleys of numerous rivers and by the lakes basins [Stankovskij, 1997]. The prevailing topographic form is glacial and aqueoglacial [Kutinov and Chistova, 2004.

The general territory outline at which investigations have been carried out is shown in Figure 1.

The geological profile of the considered region may be divided into two structural levels.

The lower level is characterized by the crystalline basement, which is composed of the low Archean geological formations represented by biotitic, biotite-amphibolitic gneisses, amphibolites, garnetiferous gneiss-granites and igneous complexes [Har'kiv et al., 1998]. The cover thickness of the crystalline basement ranges from 0.5 to $1.2 \mathrm{~km}$ for the high offsets and from 2.0 to $3.0 \mathrm{~km}$ and more in grabens and cavities, while in general the base- ment lowers in the east and southeast directions [Shirobokov, 1997].

The sedimentary sheath is composed of terrigenous or carbonaceous-terrigenous rocks of the upper Proterozoic, Paleozoic and Cenozoic with a total cover thickness of up to $4 \mathrm{~km}$ for the low parts of the crystalline basement and up to $0.5-1.2 \mathrm{~km}$ for the high offsets [Bogatikov et al., 1999].

More than 50 blow holes of ultrabasic alkali rocks, diamondiferous kimberlites inclusive, have been detected in the territory of the Zimneberezhnyi region [Verzhak et al., 2008]. Ten (10) kimberlite pipes are located in the Zolotitskoye kimberlite field. The vertical section of the kimberlite pipe has the form of a typical blasting cone, the upper part of which is often represented by a bellmouth filled with crater facie rocks. The Karpinskogo-2 and Pionerskaya pipes are two contiguous pipes with a common bellmouth, i.e. these pipes are classified as double-rooted ones.

The age of the blow holes dates back to the late Devonian or the early Carboniferous period [Sablukov, 1987].

The kimberlite pipes are contained in the upper Vendian thickness amounting to about $920 \mathrm{~m}$, represented by sediments of three suites: Ust-Pinezhskaya, Mezenskaya and Padunskaya - 


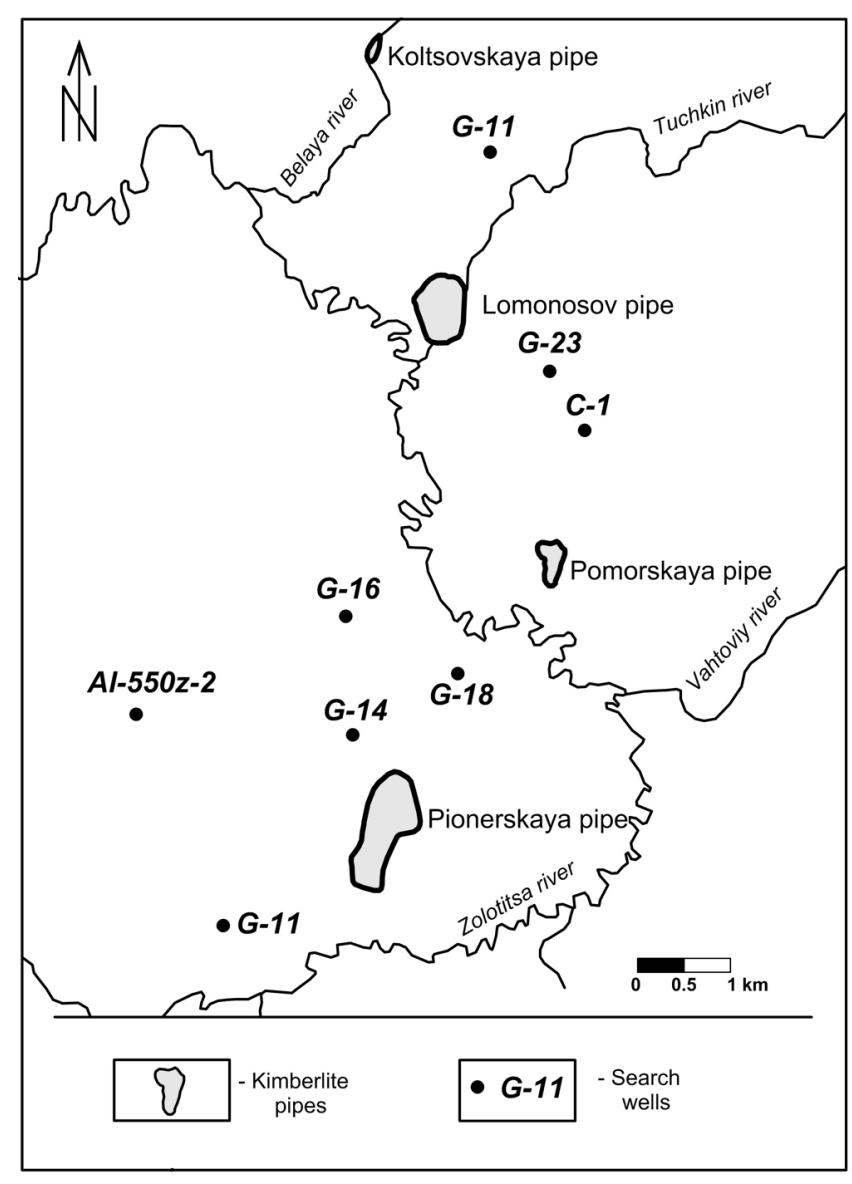

Figure 2. Location of the exploration wells in the territory in the territory of the Zolotitskoye kimberlite field.

sandstone with interlayers of siltstones.

The complex of overlapping formations is represented by middle carboniferous and quaternary deposits.

In the context of middle carboniferous deposits carbonate-terrigenous rocks of the Moscow tier predominate. These rocks can also be identified in the composition of the Urzugskaya, Voerechenskaya and Olmug and Okunev suites. In the context of the Urzugskaya suite, there are sandstones with rare low-power interlayers of siltstones. Limestones and dolomitized limestones with inclusions of flint prevail in the Voerechenskaya and Olmug and Okunev suites.

In the genetic relation, quaternary deposits are fluvioglacial, glacial, lacustrine, lacustrine-marsh and alluvial. The lithological composition of quaternary deposits is represented by sands, loam, pebbles, sandy loam and peat. The average thickness of the sediments is $35 \mathrm{~m}$.

\section{Materials and Methods}

To study the uranium isotopic composition, rock samples were taken from the cores of exploration wells left at the drilling sites (in stacks). Exploration wells were drilled in different years to verify geophysical anomalies in the territory of the Zolotitskoye kimberlite field. The location of the exploration wells, from which the material was selected for research, is shown in Figure 2, In addition, the material, represented by kimberlites of a number of the Zolotitskoye field's pipes, was processed, as well as the samples of the rocks from the near-contact space of kimberlites. By the nearcontact space we mean the area directly containing kimberlites of Vendian age deposits - exocontacts of the pipes, as well as tuffaceous-sedimentary rocks that form the peripheral parts of the crater facies. In total, the data was obtained on the uranium isotopic composition for 140 samples.

The investigation of isotopic characteristics in rock samples was carried out using alphaspectrometric methods with preliminary radiochemical isolation [Malyshev, 2013]. Specimens were prepared by grinding the rock with a mass of $100 \mathrm{~g}$ into fractions of $0.075 \mathrm{~mm}$. From the sample, which was homogenized in such a way, a $10 \mathrm{~g}$ sample was taken and subjected to complete dissolution with a solution of concentrated $\mathrm{HF}$ and $\mathrm{HClO}_{4}$ acids in a ratio of $4: 1$. The kimberlite material containing hardly soluble mineral inclusions was further sintered with $\mathrm{Na}_{2} \mathrm{CO}_{3}$ at $900^{\circ} \mathrm{C}$. After that, the rock was transferred to a nitric acid solution, from which uranium isotopes were extracted with a $30 \%$ solution of tributyl phosphate in toluene, followed by purification from interfering radionuclides with similar alpha-particle energies. To simultaneously determine the uranium content and its isotopic composition, as well as to control the completeness of the uranium output from the rocks, a tracer - an artificial long-lived isotope ${ }^{232} \mathrm{U}$ was introduced into the samples, the alpha-radiation energy of which significantly differs from the energy of the natural isotopes ${ }^{234} \mathrm{U},{ }^{235} \mathrm{U}$ and ${ }^{238} \mathrm{U}$ (4.19$4.77 \mathrm{MeV})$. The quantity of the tracer was dosed in such a way that its activity was comparable to that of natural uranium isotopes in the analyzed sample (0.0231 Bq).

Sources for alpha spectrometric detection were prepared by electrolytic deposition of uranium on 
Table 1. Isotopic Composition of Uranium in Heterochronous Sediments of the Zolotitskoye Field

\begin{tabular}{lccccc}
\hline Geol. age & $Q$ & $C_{2}$ & $V_{2}$ & $\begin{array}{c}D_{3}-C_{2} \\
\text { (Autolithic breccia) }\end{array}$ & $\begin{array}{c}D_{3}-C_{2}, V_{2} \\
\text { (Near-contact space) }\end{array}$ \\
\hline $\begin{array}{l}\text { Number of } \\
\text { samples }\end{array}$ & 10 & 31 & 54 & 13 & 32 \\
$\begin{array}{l}\text { Isotope ratio } \\
{ }^{234} \mathrm{U} /{ }^{238} \mathrm{U}, \mathrm{Bq} / \mathrm{Bq}\end{array}$ & $\frac{0.94}{0.54-1.13}$ & $\frac{0.92}{0.37-1.34}$ & $\frac{0.94}{0.46-1.20}$ & $\frac{1.00}{0.80-1.14}$ & $\frac{1.24}{0.85-3.57}$ \\
$\begin{array}{l}\text { Concentration } \\
\text { of uranium, ppm }\end{array}$ & $\frac{7.66}{0.63-46.13}$ & $\frac{1.32}{0.41-5.94}$ & $\frac{2.11}{0.32-10.73}$ & $\frac{0.67}{0.33-1.07}$ & $\frac{1.66}{0.40-5.93}$ \\
\hline
\end{tabular}

Note. Above the bar - the average values, below the bar - the minimum and maximum values.

polished stainless steel disks with a diameter of $34 \mathrm{~mm}$. The measurements were performed using a solid-state alpha spectrometer Progress with a silicon surface-barrier detector with an area of $400 \mathrm{~mm}^{2}$.

To ensure the most accurate estimations of the ratio value ${ }^{234} \mathrm{U} /{ }^{238} \mathrm{U}$ and to reduce the error of the results, each sample was measured after 3-4 exposures, approximately equal in time. In order to control and exclude possible instrumental deviations during the sample measurement, the parameters of the spectrometer were monitored by the reference source OISN-242 No. 6, comparing the peak positions and the counting rate with control values. The correctness of counting the pulses through the channels that correspond to the isotopes ${ }^{234} \mathrm{U}$ and ${ }^{238} \mathrm{U}$ was performed by the source of equilibrium uranium A2-150. The isotope ratio $\gamma={ }^{234} \mathrm{U} /{ }^{238} \mathrm{U}$ in the source A2-150 is equal to $1.01 \pm 0.02$.

The errors in measurements of isotopic ratios in the samples of kimberlites, enclosing rocks and natural waters are determined by the statistics of the number of recorded decays [Chalov, 1991]. The absolute error in measuring the intensity of the lines in this case is equal to $\sqrt{N}$ (where $N$ is the number of decays registered for a given line), and the relative error is $1 / \sqrt{N}$.

The standard deviation $(\sigma)$ of the ratio of the intensities of the two uranium's alpha peaks with the number of registered pulses $N_{234}$ and $N_{238}$, which corresponds to the ratio of the isotopic activities $\gamma={ }^{234} \mathrm{U} /{ }^{238} \mathrm{U}$, was found from the correlation:

$$
\sigma=\frac{N_{234}}{N_{238}} \sqrt{\frac{1}{N_{234}}+\frac{1}{N_{238}}}
$$

The relative mean square error is determined from the correlation:

$$
\delta=\sqrt{\frac{1}{N_{234}}+\frac{1}{N_{238}}}
$$

The mean square error in determining the activity of the examined samples by using the alphaspectrometric method was: about $2 \%$ in determining the value $\gamma$ and about $4-5 \%$ in determining the uranium concentration.

\section{Results and Discussion}

The results of uranium isotopic studies in the samples of kimberlites, the enclosing and overburden deposits of the Zolotitskoye ore field are published as the dataset by [Kiselev et al., 2018] in the Earth Sciences Database (ESDB) created and managed by the Geophysical Center RAS. In the generalized form, depending on the facial belonging of the rocks, the data is shown in Table 1.

As it is seen from the mentioned dataset and Table 1, quaternary water-glacial deposits, mainly represented by sands and sand-gravel mixture, are characterized by the highest average concentration of uranium, which is $7.66 \mathrm{ppm}$. The highest concentration of uranium is confined to quaternary sands with an admixture of dark flints enriched with uranium. The uranium concentration in it reaches $46 \mathrm{ppm}$, which is much higher than the bulk earth values. Probably, the source of uraniumbearing flints in quaternary formations was silicified interlayers of the underlying middle-upper carboniferous deposits, eroded by the glacier. 
Carboniferous deposits, composed of sands, sandstones and dolomites, have an average uranium concentration of about $1.3 \mathrm{ppm}$. The dolomites of the Olmug and Okunev suites are most enriched with uranium, about $6 \mathrm{ppm}$. The isotopic ratio $\gamma={ }^{234} \mathrm{U} /{ }^{238} \mathrm{U}$ varies within $0.37-1.34 \gamma$, the average value is $0.92 \gamma$.

For the upper section of the Vendian thickness, represented by the Padunskaya suite and mainly composed of sandstones and siltstones, the uranium concentration varies between 0.32 and $10.73 \mathrm{ppm}$, with an average value of $2.11 \mathrm{ppm}$. The uranium isotopic ratio varies within $0.46-1.20 \gamma$ and on the average is close to equilibrium.

The uranium isotopic ratio ${ }^{234} \mathrm{U} /{ }^{238} \mathrm{U}$ for the kimberlites of the ventral facies of the Arkhangelskaya, Karpinskogo-1 and Pionerskaya pipes, represented by autolithic breccia, varies within the range $0.80-1.14 \gamma$, at an average equilibrium value $\gamma$. For autolithic breccias, the lowest uranium concentration of $0.67 \mathrm{ppm}$ is also characteristic.

Sandstones and siltstones of the Vendian age, selected from the contact zones of the Arkhangelskaya, Karpinskogo-1 and Pionerskaya pipes, considerably differ in the uranium isotopic composition from the Vendian deposits from the exploration wells, selected at the Zolotitskoye field. The value of ${ }^{234} \mathrm{U} /{ }^{238} \mathrm{U}$ in it is much higher than in the enclosing rocks, which are not related to the pipes. High values of the uranium isotopic ratio are also characteristic for tuffaceous sedimentary rocks that form the peripheral parts of the crater facies. For the rocks of the near-contact space, the value of ${ }^{234} \mathrm{U} /{ }^{238} \mathrm{U}$ in average amounts to $1.24 \gamma$, with an average concentration of gross uranium of $1.66 \mathrm{ppm}$.

The uranium concentration in the Vendian samples of the Padunskaya suite from the exploration wells on average is within the limits of bulk earth values for the sedimentary cover $\sim 2 \mathrm{ppm}$ [Smyslov, 1974. However, in some Vendian samples of the Padunskaya suite, the excessive percentage abundance of $10.73 \mathrm{ppm}$ was noted. The dependence of the isotope ratio and the uranium total concentration, which is -0.4 , was found, which is characterized as a moderate negative bond. In the samples with high uranium concentration, which is several times higher than the bulk earth value, the values of ${ }^{234} \mathrm{U} /{ }^{238} \mathrm{U}$ below 0.46 are observed, due to the leaching of the light isotope ${ }^{234} \mathrm{U}$ from rocks under the influence of groundwater. The revealed regularities are probably related to the peculiarities of the hydrogen uranium redistribution in the upper section of the Vendian thickness. In the lower section of the Vendian deposits, represented by the Ust-Pinezhskaya aleurolite-argillaceous and Mezenskaya sandstone-siltstone suites, in the depth interval from 300 to $1100 \mathrm{~m}$, the processes of hydrogen-induced redistribution of uranium are not manifested, since the uranium isotopic ratio is equilibrium and the uranium concentration is about $3 \mathrm{ppm}$, which corresponds to the types of rocks forming the stratum. For sediments of other ages, such patterns are not established.

It should also be noted that the kimberlites of the examined pipes from the Zolotitskoye field are characterized by extremely low concentrations of gross uranium $\sim 0.67$. It is known that in a series of magmatic formations, alkaline-ultrabasic rocks are characterized by minimal content of radioactive elements [Arbuzov and Rihvanov, 2009]; however, for different diamond-bearing regions of the world, the variations in the uranium content are different. Thus, according to the works $[$ Lutts and Mineeva, 1973] on Yakutia's kimberlites, the content of radioactive elements, uranium in particular, is comparable with granites and characterizes the highest concentrations of $\mathrm{U}$ and $\mathrm{Th}$ in a series of subalkaline ultrabasic rocks. The uranium content in the Yakutia's kimberlites increases from the southern to the northern kimberlite areas from 2.0 to $8.2 \mathrm{ppm}$. In some pipes of the Yakutsk diamondiferous province (YaDP), high concentrations of $\mathrm{U}$ reaching $11 \mathrm{ppm}$ are established [Zverev et al., 1979. In India's kimberlites, the uranium content varies from 1.87 to $3.93 \mathrm{ppm}$ [Paul et al., 1977 .

As it can be seen from the data presented above, ADP kimberlites are characterized by substantially lower concentrations of U, compared to the known kimberlite provinces of the world. In addition, the uranium concentration in the ADP kimberlites decreases with the increase of depth, which indicates an even greater depletion of radioactive elements in the magmatic source of kimberlites. The authors of the work [Lapin and Tolstov, 2007] Frolov et al., 2005 for the ADP kimberlites have established negative anomalies of high-charged rare elements, thorium, titanium and low values of the indicator ratios $\mathrm{Ce} / \mathrm{Y}, \mathrm{Nb} / \mathrm{Zr}$ and $\mathrm{Th} / \mathrm{U}$. Based on these data, ADP kimberlites were detached into 
a separate geochemical type - D. The difference in mineral composition between D-type kimberlites and kimberlites from the traditional diamondiferous regions of Yakutia is also significant, causing its low magnetic susceptibility [Lapin and Tolstov, 2007], which makes it difficult to use the traditional methods of searching for this type of kimberlites.

The ${ }^{234} \mathrm{U} /{ }^{238} \mathrm{U}$ isotopic ratio in the ventral facies of the Zolotitskoye field's pipes is in equilibrium, indicating that in these types of kimberlites, modern processes of uranium fractionation are not shown since the vent parts are not available for groundwater circulation. At the same time, the anomalous values of ${ }^{234} \mathrm{U} /{ }^{238} \mathrm{U}$ are observed in the contact area of kimberlites with enclosing rocks, more than 3 times higher in the Pionerskaya pipe than the natural equilibrium of uranium isotopes. The majority of samples of the endocontact rocks of the pipes, represented by the upper Vendian sandstones and siltstones and exocontacts, composed of tuffaceoussedimentary formations of the peripheral parts of the crater facies, is characterized by the enrichment with the light isotope ${ }^{234} \mathrm{U}$. It should be noted that such an increase in the uranium isotope ratio is a characteristic feature of the near-contact spaces of all the pipes of the Zolotitskoye field, studied by us. In heterochronous enclosing and overburden rocks, remote from the blow holes and having no signs of kimberlite magmatism, enrichment with the ${ }^{234} \mathrm{U}$ isotope is not observed, with the exception of single cases, probably caused by local geochemical conditions, which are typical for a particular interval or for specific environments in near-surface conditions. In general, in the Quaternary and Carboniferous deposits, which are enclosing kimberlites of the Zolotitskoye field and containing kimberlites in the Vendian rocks, the average values of the isotope ratio of ${ }^{234} \mathrm{U} /{ }^{238} \mathrm{U}$ do not exceed 1 . Thus, the data obtained from this study on the existence of uranium isotopic anomalies with excessive content of the daughter ${ }^{234} \mathrm{U}$ in the near-contact space of the Zolotitskoye field's kimberlites, allows us to cautiously state that the non-equilibrium is connected with the manifestations of kimberlite magmatism in the territory of the ADP. In turn, the indicator of the non-equilibrium uranium with an excessive ${ }^{234} \mathrm{U}$ contact, emitted through the section of the enclosing Vendian deposits, can be considered as a local indirect search sign of the ADP kimberlite bodies. However, undoubtedly, the ura- nium imbalance index should be considered in conjunction with other characteristics of kimberlites, which will increase the effectiveness of assessing the manifestations of kimberlite magmatism in the sections of the exploration well. In general, the near-contact space of the kimberlite bodies of the Zolotitskoye field has a number of distinctly distinguished material and structural changes, caused by the influence of the kimberlite pipe on the enclosing rocks. Thus, local tectonic elements accompanying the exocontacts of kimberlites are revealed in the Arkhangelskaya pipe [Ignatov et al., 2008, 2012. Vasil'ev, 2010. The pipe is bounded by the zones of mylonites and steeply dipping fractures, including low-amplitude overfaults and subsidence faults. Tectonic disturbances are accompanied by enclosing and overburden deposits, and are reliably determined in the Urzugskaya Carboniferous and Padunskaya Vendian suites [Vasil'ev, 2010]. Endogenous vein lightening develops along these fracture zones [Ignatov et al., 2015]. The dimensions of the spreading aureole of secant clarification reach the diameter of the pipe and are fixed along the perimeter of the near-contact space, both directly on the tectonic contacts of the crater part of the pipe, as well as at a distance of up to $300 \mathrm{~m}$ from the pipe. The lightening develops along the cracks and has a thickness of up to $20 \mathrm{~cm}$ [Ignatov et al., 2015. Based on the study of radiation damages (RD) in the quartz of crater sandstones, enclosing Vendian rocks and overburden carbon, the elevated concentrations of RD in quartz of Vendian sandstones in the exocontact of the Arkhangelskaya pipe was found in comparison with the Vendian rocks from exploration wells [Zaripov, 2014]. High $\mathrm{RD}$ concentrations are associated with the radiation impact of uranium paleo concentrations due to its infiltration and oxidation transfer and settlement near kimberlites, obtaining recovering properties [Zaripov, 2017]. The age of uranium mineralization along the RD is 370 million years, which corresponds to the age of the formation of the Zolotitskoye field's kimberlite pipes.

It seems most probable that the structural and geological features of the kimberlite pipes of the Zolotitskoye field determine the formation of modern uranium isotopic anomalies in the near-contact space of kimberlites. The deviation from the equilibrium of the isotope pair ${ }^{234} \mathrm{U}$ and ${ }^{238} \mathrm{U}$ in the exocontacts of kimberlites testifies to the migra- 
tion of the daughter isotope over the last 1 million years, since ${ }^{234} \mathrm{U}$ surpluses are maintained for not more than 10 half-lives of uranium-234. The development of fracture zones, bounding the pipes, seems to lead to the penetration of infiltration water into the aquifers of Vendian deposits and to the change in the hydrochemical regime of groundwater, as a result of which uranium precipitates with excessive mobile isotope ${ }^{234} U$. Such processes of accumulation of radioactive element can also be observed within kimberlite controlling faults, as the disruption of the sedimentation continuity can also create conditions for infiltration water to penetrate and mix with mineralized groundwater, which leads to the formation of a geochemical barrier. The establishment of radio-geochemical features of kimberlite-controlling faults requires special attention, since there is currently no corresponding data, as well as there is no data on the general geochemical specialization of faults [Kutinov and Chistova, 2004. The nodes and zones of tectonic disturbances are accompanied by the rise of Vendian waters, the decrease in mineralization of which should occur in the contact zone with the fresh Carboniferous and Paleozoic waters [Kutinov and Chistova, 2004. The zones and nodes of ADP faults are distinguished by geochemical anomalies, which is confirmed by geochemical survey data [Glavatskih, 1992 .

Thus, the conducted studies represent a small step towards understanding the fractionation features of even uranium isotopes in the kimberlite magmatism of the Arkhangelsk province. Undoubtedly, specific geochemical conditions that are favorable for the accumulation of excessive ${ }^{234} \mathrm{U}$ content in uranium rocks should exist for the formation of non-equilibrium uranium in rocks of the sedimentary cover. Such specific conditions exist in the near-contact space of the kimberlites of the Zolotitskoye field, which has been empirically proven in this study by means of studying the isotopic composition of uranium. In the core of exploration wells, where there are no signs of kimberlite magmatism, the fractionation of uranium isotopes is manifested to a much lesser extent. However, in connection with the large number of geochemical settings, associated with the geological and tectonic conditions of the ADP, it is not possible to single out unequal uranium as a local feature of kimberlite bodies, although certain trends exist.
These problems must be solved by expanding the area of research and accumulating factual material.

\section{Conclusions}

The results of the studies on uranium isotopes in kimberlites, overburden Carboniferous and Quaternary sediments and enclosing Vendian rocks within the Zolotitskoye ADP kimberlite field come down to the following.

The uranium isotope composition was examined in the cores of exploration wells drilled at the Zolotitskoye field in different years aiming to verify geophysical anomalies. The data on the isotopic composition of uranium are obtained from a crosssection of heterochronous sediments. In differently enclosing and overburden rocks, which are remote from the blow holes and in which no signs of kimberlite magmatism could be traced, ${ }^{234} \mathrm{U}$ isotope enrichment is not observed, with the exception of some cases, probably caused by local geochemical conditions, typical for a particular depth interval or for specific environments in near-surface conditions. In general, in the Quaternary and Carboniferous deposits, which are overburden and enclosing Vendian rocks of the Zolotitskoye field's kimberlites, the average values of the isotope ratio of ${ }^{234} \mathrm{U} /{ }^{238} \mathrm{U}$ do not exceed 1.

In the majority of samples, taken from the nearcontact space, represented by the upper Vendian deposits and peripheral frequent crater facies of the pipes, excessive content of the daughter isotope ${ }^{234} \mathrm{U}$ was established. The formation of high values $\gamma={ }^{234} \mathrm{U} /{ }^{238} \mathrm{U}$ may probably be caused by the geological structure of the near-contact space. The distribution of excessive isotope ${ }^{234} \mathrm{U}$ content matches the data on tectonic and material changes in the rocks of the near-contact space, established by a number of authors. The mechanism of formation of non-equilibrium uranium with excessive ${ }^{234} \mathrm{U}$ content is explained by the dynamics and circulation of groundwater processes along the tectonic cracks, bounding the tubes. The development of cracked zones in the near-contact space of kimberlite pipes, which are a kind of alien geological formation, sharply differs from the host environment by their physical and chemical properties, resulting in the precipitation of uranium with excessive content of isotope ${ }^{234} \mathrm{U}$. 
The data on the existence of uranium-isotope anomalies with excessive content of the daughter ${ }^{234} \mathrm{U}$ in the near-contact rocks of kimberlites in the Zolotitskoye ore field, empirically established in the laboratory studies, allows us to cautiously state that the non-equilibrium is associated with the manifestations of kimberlite magmatism in the ADP territory. In turn, the indicator of the nonequilibrium uranium with an excessive ${ }^{234} \mathrm{U}$ content, emitted through the section of the enclosing Vendian deposits, can be considered as a local indirect sign of the ADP kimberlite bodies. However, the indicator of uranium imbalance should be considered only in combination with other features of kimberlites when assessing search areas for the presence of manifestations of kimberlite magmatism at the sections of exploration wells. The revealed features of the distribution of uranium isotopes in the context of the heterochronous deposits of the Zolotitskoye field require further research within other areas of the ADP with different geological and tectonic conditions and various manifestations of alkaline and ultrabasic magmatism.

Acknowledgment. The authors are sincerely grateful to the staff of the Laboratory of Environmental Radiology of FCIARctic, who assisted in conducting laboratory studies and preparing the manuscript. Sincere gratitude is expressed by Ph.D. K. B. Danilov for assistance in carrying out expedition work. The authors are also grateful to all those who created the conditions and the opportunity to carry out these studies. The work was supported by the Russian Foundation for Basic Research in the framework of the scientific project No. 16-35-00153.

\section{References}

Androsov, E. A., et al. (2004), On structural control of the location of kimberlite bodies on the example of the Arkhangelsk kimberlite province, Efficiency of Forecasting and Prospecting for Diamond Deposits: Past, Present and Future (Diamonds-50) p.9-18, FGUP VSEGEI, Saint Petersburg. (in Russian)

Antonov, Yu. V., V. I. Zhavoronkin, S. V. Slyusarev, V. I. Klyuchnikov, A. N. Slyusarev (2004), Possibilities of the method of vertical gradient of gravity in the case of a sorting of magnetic anomalies of the tube type, Bulletin of Voronezh University. Geology, No. 1, 153-158. (in Russian)
Arbuzov, S. I., L. P. Rihvanov (2009), Geochemistry of Radioactive Elements. Tutorial, Publishing house of Tomsk Polytechnic Institute, Tomsk. (in Russian)

Bogatikov, O. A., et al. (1999), Arkhangelsk Diamondiferous Province (Geology, Petrography, Geochemistry and Mineralogy), 524 pp. Publishing house of the Moscow State University, Moscow. (in Russian)

Chalov, P. I., et al. (1990), On the spatial correlation of the anomalous excess of ${ }^{234} \mathrm{U}$ in groundwater and mercury-antimony mineralization of the telethermal type, Dokl. AN SSSR, 312, No. 3, 580-583. (in Russian)

Chalov, P. I., (Ed.) (1991), Methodical guide on uranium-isotopic modeling of groundwater dynamics in conditions of active water exchange, 88 pp. Ilim, Bishkek. (in Russian)

Cyganov, V. A., et al. (2004), Modern aerogeophysical technologies - as a basis for geological and prognostic-mineragenic maps of the new generation, Collection of scientific works "Congress of graduates of the Geological Faculty of the Moscow State University on May 26, 2004" p.151-158, MSU, Moscow. (in Russian)

Frolov, A. A., et al. (2005), Carbonatites and Kimberlites (Mutual Relations, Mineralogy, Forecast), 540 pp. NIA-Priroda, Moscow. (in Russian)

Glavatskih, S. P. (1992), Geochemical criteria and methods for prospecting diamondiferous kimberlites (on the example of the Arkhangelsk kimberlite prov.), Ph.D. thesis, p.211, IMGRE, Moscow. (in Russian)

Gubajdullin, M. G. (2002), Geoenvironmental Conditions for the Development of Mineral Resources in the European North of Russia, 310 pp. M. V. Lomonosov PSU, Arkhangelsk. (in Russian)

Har'kiv, A. D., N. N. Zinchuk, A. I. Kryuchkov (1998), Native Diamond Deposits of the World, 555 pp. Nedra, Moscow. (in Russian)

Ignatov, P. A., et al. (2008), Paleotectonic structures of the Zimneberegov Diamond Area of the Arkhangelsk Region, Bull. MOIP. Otd. Geol., No. 3, 13-20. (in Russian)

Ignatov, P. A., et al. (2011), Reconstruction of kinematics of faults in closed areas according to the analysis of micro-faults in the core, Izvestiya VUZov, Geology and Exploration, No. 3, 55-60. (in Russian)

Ignatov, P. A., et al. (2012), Fold and ruptural deformations in the host and overlying strata in the open-pit mining of the Arkhangelsk kimberlite pipe, Rudy i Metally, No. 1, 42-48. (in Russian)

Ignatov, P. A., et al. (2015), Types of clarified reddish kimberlites of the Vendian-Cambrian species of the Zimneberegov area of the Arkhangelsk Region, Izvestiya VUZov, Geology and Exploration, No. 2, 15-21. (in Russian)

Kiselev, G. P. (1999), Even Uranium Isotopes in 
the Geosphere, 220 pp. UB RAS, Ekaterinburg. (in Russian)

Kiselev, G. P. (2005), The forecast of mineral deposits and contamination of the geological environment by the uranium-isotope methods, Ph.D. thesis, p.50, IEEP UB RAS, Arkhangelsk. (in Russian)

Kiselev, G. P., et al. (2011), Nonequilibrium uranium in the rocks of the Mezen syneclise, Materials of the IV Youth Scientific Conference ECOLOGY p.2930, IEEP UB RAS, Arkhangelsk. (in Russian)

Kiselev, G. P., E. Yu. Yakovlev, S. V. Druzhinin, S. B. Zykov, V. M. Bykov, A. A. Ocheretenko (2018), Uranium isotope composition of kimberlites, the enclosing and overburden deposits of the Zolotitskoye ore field, Dataset, GS RAS, Moscow. Crossref

Kontarovich, R. S., V. A. Cyganov (2000), Problems and Prospects for the Development of Geophysical Technologies in the Arrivals of Diamond Core Areas, Geophysics, No. 4, 52-57. (in Russian)

Korotkov, Yu. V. (2011), On the issue of the allocation and tracing of discontinuous violations by the characteristic changes in conductivity in the sedimentary strata, Geophysical Research, 12, No. 4, 81-92. (in Russian)

Kutinov, Yu. G., Z. B. Chistova (2004), Hierarchical Series of Manifestations of Alkaline-Ultrabasic Magmatism in the Arkhangelsk Diamondiferous Prov., Their Reflection in Geological and Geophysical Materials, 281 pp. IEEP UB RAS. IPP "Pravda Severa", Arkhangelsk. (in Russian)

Lapin, A. V., A. V. Tolstov (2007), Geochemical types of kimberlites, Alkaline Magmatism and its Ore Content p.139-142, Logos, Kiev. (in Russian)

Lutts, B. G., I. G. Mineeva (1973), Uranium and thorium in Kimberlites of Siberia, Geochemistry International, No. 11, 1721-1724.

Magomedova, A. Sh., V. V. Udoratin (2016), Bulk activity of radon explosion tubes and magnetic anomalies of Middle Timan, Materials of the XVII Ural Youth Scientific School on Geophysics p.110-112, IHF UB RAS, Ekaterinburg. (in Russian)

Magomedova, A.Sh., V.V. Udoratin, Yu. E. Ezimova (2015), Reflection of fault zones and blast tubes of Middle Timan in geophysical fields, Bulletin of the $I G$ Komi Scientific Center UB RAS, No. 10, 28-34. (in Russian)

Malyshev, V. I., (Ed.) (2013), The method for measuring the specific activity of uranium isotopes $\left({ }^{238} \mathrm{U}\right.$, $\left.{ }^{234} U,{ }^{235} U\right)$ in samples of soils, soils, bottom sediments, rocks and building materials based on them using an alpha-spectrometric method with radiochemical preparation, $18 \mathrm{pp}$. VIMS, Moscow. (in Russian)

McDowall, G., H. Koketso (1991), Radon emanometry over some kimberlites and lamproites in Southern and Western Botswana, 53rd EAEG Meeting Crossref

Mwenifumbo, C. J., B. A. Kjarsgaard (1999), Gammaray logging and radioelement distribution in the Fort de la corne kimberlite pipe 169, Exploration and Mining Geology, 8, No. 12, 137-147.

Paul, D. K., N. H. Gale, P. G. Harris (1977), Uranium and thorium abundances in Indian kimberlites, Geochimica et Cosmochimica Acta, 41, No. 2, 335339.

Ramadass, G., A. SubhashBabu, G. Udaya Laxmi (2015), Structural analysis of airborne radiometric data for identification of kimberlites in parts of Eastern Dharwar Craton, International Journal of Science and Research, 4, No. 4, 2375-2388.

Sablukov, S. M. (1987), Some Features of the Internal Structure of Kimberlite Pipes, 37-41 pp. TsNIGRI, Moscow. (in Russian)

Shirobokov, V. N. (1997), Some features of the deep structure of the Zimneberezhny diamondiferous region, Exploration and Protection of Mineral Resources, No. 5, 21-25. (in Russian)

Smyslov, A. A. (1974), Uranium and Thorium in the Earth's Crust, 231 pp. Nedra, Leningrad. (in Russian)

Stankovskij, A. F. (1997), Wend of the South-Eastern White Sea, Exploration and Protection of Mineral Resources, No. 5, 4-9. (in Russian)

Stognij, V. V., Yu. V. Korotkov (2010), Search for Kimberlite Bodies by the Method of Transient Processes, $121 \mathrm{pp}$. Malotirazhnaya tipografiya 2D, Novosibirsk. (in Russian)

Titaeva, N. A. (2005), Geochemistry of Natural Radioactive Decay Series, 328 pp. GEOS, Moscow. (in Russian)

Tihonov, A. I. (2009), Nonequilibrium Uranium in Conditions of Active Water Exchange and its Use in Geology and Hydrogeology, 458 pp. Publishing house L. A. Naumova, Cheboksary. (in Russian)

Vasil'ev, I. D. (2010), The geological structures in the contact zone of the Arkhangelsk pipe and their use for prospecting of primary diamond deposits in the Zimneberezhnoy district, Ph.D. thesis, MGRI-RGGRU, Moscow. (in Russian)

Verzhak, V. V., et al. (2008), The experience in diamond deposits searching in the Arkhangelsk diamond province and adjacent areas or the north of the East European Platform, Problems of Forecasting and Searching of Diamond Deposits in Covered Spaces: Proc. Conf. Devoted to the 40th Anniversary of the Yakut Research Geological Exploration Company of Central Research Institute of Geological Survey ALROSA p.308-314, JSC, Yakutsk. (in Russian)

Yakovlev, E. Yu., $\quad$ G. P. Kiselev, S. V. Druzhinin (2016), Nonequilibrium uranium in kimberlites and host rocks of the Pionerskaya deposit M. V. Lomonossov, Bulletin NArFU. Series of Natural Sciences, No. 1, 19-28. (in Russian)

Zaripov, N. R. (2017), Clarification of the red-colored rocks of the Zimneberezhny diamondiferous region of the Arkhangelsk province and the Nakynsky diamondiferous field of the Yakut province, its connection with the kimberlite control structures, Ph.D. thesis, 
p.23, MGRI-RGGRU, Arkhangelsk. (in Russian) Zaripov, N. R. (2014), The first data on radiation defects in sedimentary rocks in the Zimneberegov district of the Arkhangelsk region Earth sciences. Current status, Materials of the II All-Russian Youth Scientific-Practical School-Conference p.106-108, NGU, Novosibirsk. (in Russian)

Zverev, V. L., et al. (1979), Uranium Isotopes in Kimberlite Magmatism in the Eastern Siberia, Report of the Academy of Science of the USSR, 245, No. 4, 946-950. (in Russian)

Zverev, V. L., et al.
Uranium Isotopes in the Process of Kimberlite Magmatism, Geochemistry International, No. 12, 1884 1886. (in Russian)

S. V. Druzhinin, A. A. Ocheretenko, E. Yu. Yakovlev, S. B. Zykov, N. Laverov Federal Centre for Integrated Arctic Research (FCIARctic), 109 Nabereznaya Severnoy Dviny, Arkhangelsk, Russia.(yakovlev_eu@inbox.ru)

V. M. Bykov, Northern (Arctic) Federal University, 17 Nabereznaya Severnoy Dviny, Arkhangelsk, Russia 